\title{
Ketogenic Diet and Mood Disorder
}

\section{Ketojenik Diyet ve Duygudurum Bozukluğu}

\author{
Mustafa BAYRAKTAR ${ }^{1}$, Hacı Ahmet AYDEMIR ${ }^{1}$ \\ ${ }^{1}$ Ataturk University Medical Faculty, Department of Family Medicine, Erzurum
}

$\ddot{\text { Öz }}$

Ketojenik diyetin, depresyon ve duygudurum bozuklukları tedavisinde etkinliğini gösteren çalıșmalar, tamamen sağlıklı bireylerin ketojenik diyet sonrası, duygudurum değişikliği ve bozukluğu oluşabileceği ihtimalini ve araştırılması gerektiği gerçeğini akıllara getirmektedir. Bu çalışmada, literatürde ilk kez, ketojenik diyet uygulayan ve psikiyatrik hastalığı olmayan bireylerde duygudurum bozuklukları araştırılmıştır. Tibbi amaç olmaksızın ketojenik diyet uygulayan 18-65 yaş arası erkek ve kadın gönüllüler çalışmaya alınarak, web tabanlı anket sorularını cevaplamaları istenmiștir. Duygudurum bozukluğunun taranması için "Duygudurum Bozukluğu Ölçeği”” uygulanmıştır. Psikiyatrik herhangi bir hastalığı olmayan 60 katılımcı çalıșmaya dâhil edilmiştir. Katılımcıların ketojenik diyet yapma süreleri ortalama 5.7 aydı. Katılımcılarda duygudurum bozukluğu, genel popülasyonda beklenenden daha yüksek oranda, \%26.7 oranında tespit edilmiştir. Duygudurum bozukluğu ile katılımcıların yaşı arasında istatistiksel anlamlı ilișki varken $(\mathrm{p}=0.029)$, duygudurum bozukluğu ile cinsiyet, beden kitle endeksi, obezite sınıflandırması ve ketojenik diyet süreleri arasında anlamlı ilişki bulunmamıștır $(\mathrm{p}>0.05)$. Duygudurum bozukluğu pozitif saptanan bireyler, daha konuşkan, kendine güvenen, daha az uyuyan, düşünceleri daha hızlı, daha kolay dikkati dağılan, daha sosyal, cinsellikle daha fazla ilgilenen ve daha fazla para harcayan kişiler oldukları tespit edildi ve istatistiksel olarak bu durumları anlamlı bulundu $(\mathrm{p}<0.05)$. Çalışmamızda, ketojenik diyet uygulanan bireylerde duygudurum bozukluğu yüksek bir oranda, $\% 26.7$ oranında saptanmıștır. $\mathrm{Bu}$ sonuç, ketojenik diyet uygulanan bireylerde duygudurum bozukluğunun taranmasını ve riskli bireylerde ketojenik diyet uygularken dikkat edilmesi gerektiğini ortaya koymaktadır.

Anahtar Kelimeler: Bipolar Bozukluk, Duygudurum Bozukluğu, Ketojenik Diyet, Ölçek

\section{Introduction}

The ketogenic diet was first used in the 1920s in the treatment of epilepsy as a type of diet in which the amount of carbohydrates was reduced and the amount of fat content increased (1). The ketogenic diet, first applied by Peterman at Mayo Clinic, is based on the dietary intake of one gram of protein per kilogram, 10 to 15 grams of carbohydrate per day, and fat for the rest of the calorie needs, and this calculation is still used today $(2,3)$. As the primary energy source of the body, carbohydrates are reduced to less than 50 grams per day or completely removed from the diet, insulin production decreases

\begin{tabular}{ll}
\hline & ORCID No \\
Mustafa BAYRAKTAR & $0000-0001-8486-9915$ \\
Hac1 Ahmet AYDEMIR & $0000-0001-9656-5089$
\end{tabular}

Başvuru Tarihi / Received: $\quad$ 06.06.2020

Kabul Tarihi / Accepted : $\quad 10.04 .2021$

Adres / Correspondence : $\quad$ Mustafa BAYRAKTAR

Ataturk University Medical Faculty, Department of Family Medicine, Erzurum

e-posta / e-mail mustafabayraktar@atauni.edu.tr

\begin{abstract}
Studies investigating the effectiveness of the ketogenic diet in the treatment of depression and mood disorders bring to mind the possibility that a healthy individual may develop a mood disorder after a ketogenic diet. In this study, for the first time in the literature, it was aimed to investigate mood disorders in psychiatrically healthy individuals who are following a ketogenic diet. Volunteers between the ages of 18-65, who went on a ketogenic diet without medical purposes, were included in the study and asked to answer web-based questions including the "Mood Disorder Questionnaire". Sixty participants, who did not have any known psychiatric illnesses, and who did not use any psychiatric medications were included. The mean duration of the participants' ketogenic diet was 5.7 months. The ratio of the mood disorder was found to be $26.7 \%$. A statistical difference was found between mood disorder and age $(\mathrm{p}=0.029)$; but no significance was detected between mood disorder and gender, body mass index, obesity and diet durations. Those with positive mood disorders were more active, more social and talkative, more self-confident, less sleepy, more interested in sexuality, spent more money, easily distracted, thoughts were faster in their minds and all these differences were statistically significant $(\mathrm{p}<0.05)$. The present study found the rate of mood disorders to be $26.7 \%$ in individuals who were following a ketogenic diet. This reveals the necessity of screening for mood disorders in individuals on ketogenic diet and the necessity of avoiding ketogenic diet in patients at risk.
\end{abstract}

Keywords: Bipolar Disorder, Mood Disorder, Ketogenic Diet, Questionnaire

and the body goes into a catabolic state, triggering gluconeogenesis and ketogenesis metabolic pathways (4).

It has been determined that the ketogenic diet suppresses the urge to eat, which is effective in combating obesity, and reduces cardiovascular risks by providing short and medium-term glycemic control over type 2 diabetes and HDL cholesterol levels (5). In addition, there are studies suggesting that high ketone levels can be used in the treatment of diseases such as Alzheimer's and Parkinson's by improving the neuroprotective effect and cognitive functions in the hippocampus (6). The ketogenic diet has also been used in the treatment of anxiety and depression due to its effects on neurotransmitters such as serotonin and dopamine (7).

Mood disorders are generally divided into two as major depressive disorder and bipolar disorders presenting with hypomanic or manic episodes. The lifetime prevalence of bipolar disorder in society was found to be $1 \%$ to $5 \%(8,9)$. In studies investigating the incidence of mood disorders in specified groups, mood disorders were found to be in $14.4 \%$ in 
hospitalized patients, $7.2 \%$ in pregnant women, and $54.3-61.5 \%$ in anorexia and bulimia patients (1012).

In the literature there are multiple studies investigating the effects of ketogenic diet on the treatment of the mood disorders $(13,14)$. However, these studies have mostly been conducted on a small number of patients. Due to its unknown effects on the body, there are still doubts that ketogenic diet can be used as a treatment alternative for psychiatric and mental illnesses (15).

Studies showing the effectiveness of the ketogenic diet in the treatment of depression and mood disorders bring to mind the possibility that a completely healthy individual may advance a mood change and develop especially bipolar disorder after a ketogenic diet, and it needs to be investigated.

In this study, for the first time in the literature, it was aimed to investigate mood disorders by conducting the Mood Disorder Questionnaire, by investigating hypomania and mania symptoms to screen bipolar disorders in individuals who were on ketogenic diets and who did not have any psychiatric diseases.

\section{Material and Method}

The study was conducted as a prospective crosssectional study, between July and October 2019. Prior to the study, Ethics Committee approval was obtained from the Clinical Research Committee of Ataturk University Faculty of Medicine, with the decision date and number of 27.06.2019/05-02. The study was conducted in accordance with the Good Clinical Practice criteria of the Helsinki Declaration. In the study, individuals on a ketogenic diet were asked to answer web-based questionnaire. By giving the necessary explanations and information about the study, there is an option at the beginning of the questionnaire whether they want to answer the questionnaire or not. If they agree to participate in the survey, the survey questions are opened to be answered, otherwise the survey will be terminated. Individuals, who voluntarily agreed to answer the questionnaire, were not asked to sign an additional informed consent form.

This study was conducted among members of the ketogenic diet group, a nationwide group of members who were on a ketogenic diet and come together to motivate and support each other on a social platform. The universe of the study was a social media platform joined by those on a ketogenic diet. The sample size of the study was not calculated and all members of the social group were tried to be reached with voluntary participation. Male and female participants between the ages of 18-65, who were on a ketogenic diet voluntarily without medical purposes, were included in our study.

The first issues questioned in our study are whether individuals have any psychiatric disorders.
Patients with a psychiatric illness or using a psychiatric medication for any reason were excluded from the study.

In our study, it was questioned whether the individuals entered ketosis or not. To determine this, the participants tested whether they were ketosis positive by detecting ketones in the urine with the strip method, which is sold in pharmacies and purchased by themselves. With this method, individuals can easily see whether they are ketone positive according to the color change on the strip. Since the mood disorders of individuals, who had ketosis at a time, were screened in our study, individuals negative for ketosis were excluded from the study. Taking into account the positive periods of ketosis, they were asked to answer questions whether they thought they were different and unusual.

For the detection and diagnosis of the mood disorders, screening tests are used in epidemiological assessments as an easy way to conduct, which is practical, cost-effective and quick method. Screening tests consisting of short questionnaires are recommended in studies to reach easily to the people who need to be evaluated in more detail for the diagnosis of mood disorder (16).

In our study, the Mood Disorder Questionnaire (MDQ) survey was conducted for the screening of mood disorder from participants who were positive for ketosis. The MDQ, which is a scale used for the screening and detection of mood disorders, had validity and reliability tests and yielded good sensitivity (0.73) and very good specificity (0.90) based on the Diagnostic and Statistical Manual of Mental Disorders, fourth edition (DSM-IV) criteria (17). Also, its validity and reliability were investigated with its Turkish version (18). Studies in the literature have also shown that MDQ is more sensitive and specific in the screening of bipolar disorders rather than the uniform major depressions (19).

MDQ is a self-reporting survey scale that includes "yes" and "no" answers, taking its origin from the DSM-IV and consists of three questions. The first question consists of 13 sub-items and examines hypomanic and manic behavior changes such as elevated mood, irritability, assertiveness, sleep, libido, thought, attention and energy increase. Individuals, who answer yes to seven or more of these questions, are diagnosed with mood disorder. The second question investigates whether the symptoms coexist simultaneously, while the third question examines the effect of these symptoms on functionality.

After the survey was conducted, the results were evaluated with the IBM-SPSS 23.0 package program. While categorical variables were expressed as frequencies and percentages, numerical variables were shown in mean and standard deviations, if normal distribution was assessed; and 
in median and interquartile ranges (IQR), if there was no normal distribution. The Shapiro-Wilk test was used for the determination of the normal distribution. If the compared groups are two groups and are not normally distributed, the Mann-Whitney $\mathrm{U}$ test was performed. Besides, the chi square test was used for investigation of the relationships between independent categorical variables. For statistical significance, $\mathrm{p}<0.05$ was accepted in the whole study.

\section{Results}

The number of participants was 96, who were voluntarily participated in our study and answered "yes" to agree to answer the questionnaire. From the duplicate responses, the first answers were accepted, the next answers were excluded from the study, and thus the number of questionnaires received for evaluation was 83. Participants over the age of 65 were excluded because the study was conducted with participants aged 18-65.

In our study, the state of having psychiatric illness and any psychiatric drug use, which are among the exclusionary conditions, were primarily investigated. Of the participants, 10 patients, who had a psychiatric illness, and three patients, who used psychiatric medications, were excluded from the study.

It was investigated whether the remaining 69 patients entered ketosis while on a ketogenic diet, and it was determined that nine people were not in ketosis, and therefore they were excluded from the study. Once ketone positivity was detected, the person was considered ketone positive and included in the study. Since, as long as the body is deprived of carbohydrates, metabolism remains in the ketotic state. Participants were considered to be cautious of their diet and to perpetuate themselves in constant states of ketosis, for this reason they intended to come together, to give motivation and support to each other on a social platform.

As a result, 60 patients, who did not have any psychiatric illnesses or psychiatric drug use and who had been on ketosis while on a ketogenic diet, were included in the study and answered the Mood Disorder Questionnaire (Figure 1. Flow chart of the study).

The general characteristics of the participants included in our study are given in Table 1. Accordingly, eight participants (13.3\%) were male, and $52(86.7 \%)$ were female volunteers; their ages ranged from 23 to 61 years of age, and the average age was $42.3 \pm 9.5$ years. Men's median weight was $87.5 \mathrm{~kg}(\mathrm{IQR}=26.0)$, while women's median weight was $68.0 \mathrm{~kg}(\mathrm{IQR}=14.0)$; and the median weight of all participants was 68.8 (IQR=16.8). Weight value was found statistically significant according to the gender $(\mathrm{p}<0.001)$. The median body mass indexes (BMI) of men and women were $27.4 \mathrm{~kg} / \mathrm{m}^{2}$
$(\mathrm{IQR}=9.9, \min =24.3, \max =37.7)$ and $25.9 \mathrm{~kg} / \mathrm{m}^{2}$ $(\mathrm{IQR}=5.0$, $\min =20.8, \max =39.4)$, respectively; and the median BMI of all participants was 26.0 (IQR=5.3). Of all participants, 24 people $(40 \%)$ had normal BMI, while $23(38.3 \%)$ were overweight and $13(21.7 \%)$ were obese. However, BMI and obesity degrees were not statistically different between genders $(\mathrm{p}>0.05)$.

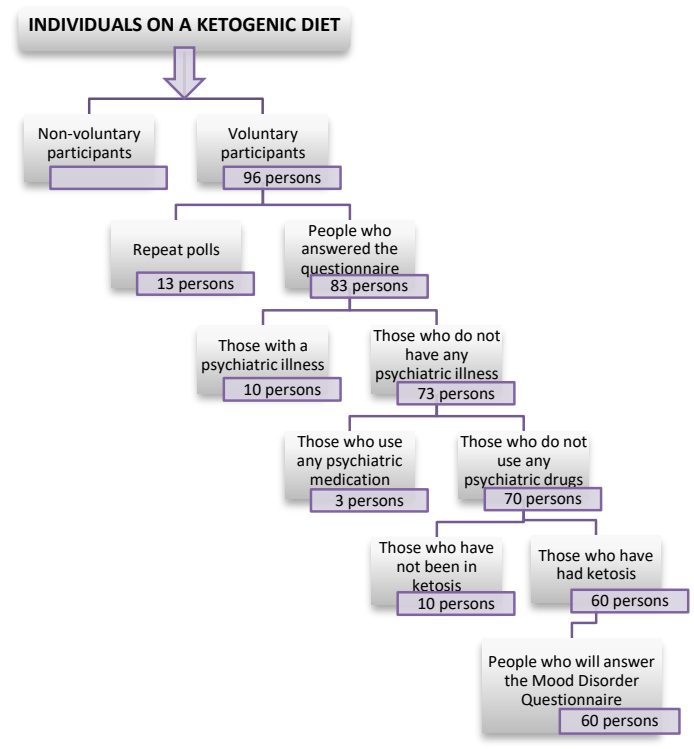

Figure 1. The flow chart of the study

Table 1. General features of the participants.

\begin{tabular}{|c|c|c|c|c|}
\hline \multirow{2}{*}{ Number of participant } & Total & Men & Women & $\mathbf{p}$ \\
\hline & $\begin{array}{c}60 \\
(\% 100)\end{array}$ & $\begin{array}{c}8 \\
(\% 13.3)\end{array}$ & $\begin{array}{c}52 \\
(\% 86.7)\end{array}$ & \\
\hline Age (Year) & $42.3 \pm 9.2$ & $42.3 \pm 7.1$ & $42.3 \pm 9.5$ & 1.000 \\
\hline Weight (kg) & $\begin{array}{c}68.8 \\
(\mathrm{IQR}=16.8)\end{array}$ & $\begin{array}{c}87.5 \\
(\mathrm{IQR}=26.0)\end{array}$ & $\begin{array}{c}68.0 \\
(\mathrm{IQR}=14.0)\end{array}$ & $<0.001$ \\
\hline $\operatorname{BMI}\left(\mathrm{kg} / \mathrm{m}^{2}\right)$ & $\begin{array}{c}26.0 \\
(\mathrm{IQR}=5.3)\end{array}$ & $\begin{array}{c}27.4 \\
(\mathrm{IQR}=9.9)\end{array}$ & $\begin{array}{c}25.9 \\
(\mathrm{IQR}=5.0)\end{array}$ & 0.061 \\
\hline $\begin{array}{l}\text { Normal } \\
(\mathrm{n}, \%)\end{array}$ & $\begin{array}{c}24 \\
(40 \%)\end{array}$ & $\begin{array}{c}2 \\
(25 \%)\end{array}$ & $\begin{array}{c}22 \\
(42.3 \%)\end{array}$ & \\
\hline $\begin{array}{l}\text { Overweight } \\
(\mathrm{n}, \%)\end{array}$ & $\begin{array}{c}23 \\
(38.3 \%)\end{array}$ & $\begin{array}{c}3 \\
(37.5 \%)\end{array}$ & $\begin{array}{c}20 \\
(38.5 \%)\end{array}$ & \\
\hline 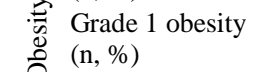 & $\begin{array}{c}9 \\
(15 \%)\end{array}$ & $\begin{array}{c}1 \\
(12.5 \%)\end{array}$ & $\begin{array}{c}8 \\
(15.4 \%)\end{array}$ & 0.171 \\
\hline $\begin{array}{l}\text { Grade } 2 \text { obesity } \\
(\mathrm{n}, \%)\end{array}$ & $\begin{array}{c}4 \\
(6.7 \%)\end{array}$ & $\begin{array}{c}2 \\
(25 \%)\end{array}$ & $\begin{array}{c}2 \\
(3.8 \%)\end{array}$ & \\
\hline $\begin{array}{l}\text { Grade } 3 \text { obesity } \\
\text { (n, \%) }\end{array}$ & $\begin{array}{c}0 \\
(0 \%)\end{array}$ & $\begin{array}{c}0 \\
(0 \%)\end{array}$ & $\begin{array}{c}0 \\
(0 \%)\end{array}$ & \\
\hline $\begin{array}{l}\text { Chronic disease } \\
\text { existence }\end{array}$ & $\begin{array}{c}17 \\
(28.3 \%)\end{array}$ & $\begin{array}{c}3 \\
(37.5 \%)\end{array}$ & $\begin{array}{c}14 \\
(26.9 \%)\end{array}$ & 0.676 \\
\hline $\begin{array}{l}\text { Ketogenic diet } \\
\text { duration } \\
\text { (month) }\end{array}$ & $\begin{array}{c}3.0 \\
(\mathrm{IQR}=7.6)\end{array}$ & $\begin{array}{c}3.5 \\
(\mathrm{IQR}=9.0)\end{array}$ & $\begin{array}{c}3.0 \\
(\mathrm{IQR}=7.3)\end{array}$ & 0.742 \\
\hline
\end{tabular}

Seventeen $(28.3 \%)$ respondents said they had a chronic disease, while $43(71.7 \%)$ participants said they were healthy.

The median duration of the participants' ketogenic diet was 3.0 months (IQR=7.6). While weight loss and staying healthy were the most common reasons offered by the participants for following a ketogenic diet, one participant stated that they followed a ketogenic diet in order to feel 
energetic, one participant commented that they sought to overcome the effects of hypothyroidism, and one participant referenced the desire to control their diabetes.

The presence of a mood disorder was indicated by the participants answering "yes" to seven of the 13 sub-questions that comprised the first MDQ question. When the responses given by the participants to the MDQ questionnaire were examined, the number of participants found to have a mood disorder was $16(26.7 \%)$. The identified mood disorders were found to be positive in two men $(25 \%)$ and 14 women (26.9\%), although there was no statistically significant difference between the genders in this regard $(p>0.05)$. Twelve of the 16 participants found to experience mood disorders (20\% of all participants) answered "yes" to the second MDQ question, which asked whether their symptoms were simultaneous. In terms of the third MDQ question, only one participant reported that their mood disorder moderately impaired their functionality, while five participants reported their functionality to be impaired to a small degree, and the other participants reported that their functionality was not impaired.

Over $80 \%$ of participants answered "yes" to the two questions that asked whether they felt more energetic than usual and more active than before $(88.3 \%$ and $83.3 \%$, respectively). All the participants $(100 \%)$, whose mood disorders were found to be positive, answered "yes" to these two questions. Two participants (less than $10 \%$ of all participants) answered "yes" to the questions that asked whether they frequently engaged in risky and absurd behavior and frequently found themselves in trouble due to spending excessive money $(8.3 \%$ and $10 \%$, respectively). Based on the evaluation, when compared with those participants whose mood disorders were found to be negative, those, whose mood disorders were positive, trusted themselves more, slept less, were more talkative, thoughts flowed faster in their minds, were more easily distracted, were more social, were more interested in sex, and spent more money, and all these differences were found to be statistically significant (see Table 2).

The relationships between the identified mood disorders and the participants' characteristics are presented in Table 3. While the mean age of those participants with positive mood disorders was $38 \pm 10.68$ years, the mean age of the participants with negative mood disorders was $43.8 \pm 8.12$ years, and a statistical difference was found in terms of the relation between age and mood disorder $(p=0.029)$. In terms of the analysis of the participants with a chronic disease and the relationship between having a chronic disease and having a mood disorder, the identified mood disorders were found to be positive and statistically significant in those participants who did not have a chronic disease $(\mathrm{p}=0.025)$. However, no significant relationship was found between having a mood disorder and the participants' gender, weight, BMI, obesity classification, and ketogenic diet duration $(\mathrm{p}=1.000, \mathrm{p}=0.676, \mathrm{p}=0.732, \mathrm{p}=0.546$, and $\mathrm{p}=0.879$, respectively).

\section{Discussion}

To the best of our knowledge, this study is the first to investigate mood disorders in psychiatrically healthy individuals who are following a ketogenic diet. Within the scope of the MDQ questionnaire, the present study found the rate of mood disorders to be $26.7 \%$ in individuals, who were following a ketogenic diet, who did not have any known psychiatric illnesses, and who did not use any psychiatric medications. Although the diagnoses of mood disorders in the participants were not confirmed by a psychiatrist, prior studies have shown a consistent effect whereby the MDQ questionnaire was determined to be the best instrument for screening bipolar disorders based on the DSM-IV criteria (20). Therefore, given the higher sensitivity and specificity rates of the MDQ, the results of this study indicate that mood disorders have a higher prevalence than reported in the literature, with the rate being six to ten times higher than expected $(1 \%$ to $5 \%)(21,22)$, in individuals following a ketogenic diet.

In the present study, a statistically significant relationship was found between having a mood disorder and being of a lower age and not suffering from any chronic disease. In the literature, it has been reported that an earlier onset of bipolar disorder is associated with worse and more negative outcomes (23). Since the mean age of the participants in this study was 42 years, although a ketogenic diet tends to be preferred and followed by younger obese people, the increased risk of bipolar disorder should be kept in mind and individuals should be mindful of any symptoms.

In this study, the likelihood of experiencing bipolar disorder was found to be low in those individuals with a chronic disease. It is, therefore, assumed that a ketogenic diet only switches those individuals from experiencing the depressive moods expected in the presence of chronic diseases to normal mood levels. An experimental study designed to investigate the antidepressant properties of the ketogenic diet found rats that were administered the ketogenic diet to be more active than the control group, which is a parallel result to the result of this study (7).

In a study conducted among humans, the ketogenic diet for weight-loss purposes and low-fat diet groups were compared, and somatic symptoms such as hunger, weakness, and insomnia were evaluated (24). Although similar results were obtained for both groups, it was found that those on a ketogenic diet showed a greater improvement in relation to their negative emotions. 
Table 2. Answers to the questionnaire.

\begin{tabular}{|c|c|c|c|}
\hline \multirow[b]{2}{*}{ Has there ever been a period of time when you were not your usual self and... } & \multicolumn{2}{|c|}{ "Yes" Answer (n, \%) } & \multirow[b]{2}{*}{$\mathrm{p}$} \\
\hline & $\begin{array}{l}\text { Mood Disorder } \\
\text { Negative } \\
(n=44)\end{array}$ & $\begin{array}{c}\text { Mood } \\
\text { Disorder } \\
\text { Positive } \\
(\mathbf{n}=16)\end{array}$ & \\
\hline $\begin{array}{l}\text {... you felt so good or so hyper that other people thought you were not your normal } \\
\text { self or you were so hyper that you got into trouble? }\end{array}$ & $6(13.6 \%)$ & $6(37.5 \%)$ & 0.066 \\
\hline ... you were so irritable that you shouted at people or started fights or arguments? & $12(27.3 \%)$ & $5(31.3 \%)$ & 0.756 \\
\hline ... you felt much more self-confident than usual? & $24(54.5 \%)$ & $16(100 \%)$ & 0.003 \\
\hline ... you got much less sleep than usual and found that you didn't really miss it? & $29(65.9 \%)$ & $15(93.8 \%)$ & 0.046 \\
\hline ... you were more talkative or spoke much faster than usual? & $7(15.9 \%)$ & $11(68.8 \%)$ & $<0.001$ \\
\hline ... thoughts raced through your head or you couldn't slow your mind down? & $13(29.5 \%)$ & $11(68.8 \%)$ & 0.015 \\
\hline $\begin{array}{l}\text {... you were so easily distracted by things around you that you had trouble } \\
\text { concentrating or staying on track? }\end{array}$ & $5(11.4 \%)$ & $8(50 \%)$ & 0.003 \\
\hline ... you had much more energy than usual? & $37(84.1 \%)$ & $16(100 \%)$ & 0.173 \\
\hline ... you were much more active or did many more things than usual? & $34(77.3 \%)$ & $16(100 \%)$ & 0.050 \\
\hline $\begin{array}{l}\text {.. you were much more social or outgoing than usual, for example, you telephoned } \\
\text { friends in the middle of the night? }\end{array}$ & $3(6.8 \%)$ & $9(56.3 \%)$ & $<0.001$ \\
\hline ... you were much more interested in sex than usual? & $7(15.9 \%)$ & $11(68.8 \%)$ & $<0.001$ \\
\hline $\begin{array}{l}\text {... you did things that were unusual for you or that other people might have thought } \\
\text { were excessive, foolish or risky? }\end{array}$ & $4(9.1 \%)$ & $1(6.3 \%)$ & 1.000 \\
\hline ... spending money got you or your family in trouble? & $1(2.3 \%)$ & $5(31.3 \%)$ & 0.004 \\
\hline $\begin{array}{l}\text { If you checked YES to more than one of the above, have several of these ever } \\
\text { happened during the same period of time? }\end{array}$ & $16(36.4 \%)$ & $12(75 \%)$ & 0.018 \\
\hline $\begin{array}{l}\text { How much of a problem did any of these cause you- like being unable to work; } \\
\text { having family, money or legal troubles; getting into arguments or fights? }\end{array}$ & & & 0.048 \\
\hline
\end{tabular}

Table 3. The statistical analyses of the features of the participants with mood disorder.

\begin{tabular}{lccc}
\hline & $\begin{array}{c}\text { Mood } \\
\text { Disorder } \\
\text { Negative }\end{array}$ & $\begin{array}{c}\text { Mood } \\
\text { Disorder } \\
\text { Positive }\end{array}$ & $\mathrm{p}$ \\
\hline Female gender & $\begin{array}{c}38 \\
(86.4 \%)\end{array}$ & $\begin{array}{c}14 \\
(87.5 \%)\end{array}$ & 1.000 \\
Age & $43.8 \pm 8.1$ & $\begin{array}{c}38.0 \pm \\
10.9\end{array}$ & $\mathbf{0 . 0 2 9}$ \\
Weight & $72.0(17)$ & $\begin{array}{c}67.0 \\
(15.5)\end{array}$ & 0.676 \\
BMI value & $26.0(5.2)$ & $26.3(6.8)$ & 0.732 \\
$\begin{array}{l}\text { Obesity } \\
\text { classification } \\
\text { (Normal body }\end{array}$ & 18 & $6(37.5 \%)$ & 0.546 \\
$\begin{array}{l}\text { weight) } \\
\text { Chronic disease } \\
\text { presence }\end{array}$ & 16 & $1(6.3 \%)$ & $\mathbf{0 . 0 2 5}$ \\
$\begin{array}{l}\text { Ketogenic diet } \\
\text { duration }\end{array}$ & $2.5(86.8 \%)$ & $3.0(3.4)$ & 0.879 \\
\hline
\end{tabular}

In a case report that examined the effects of following a ketogenic diet in two individuals with bipolar disorder, it was concluded that the ketogenic diet as a valid option for achieving mood stabilization (25).

In a recent study, it was determined that there was no significant difference in the cognitive functions, including learning, memory, and sleep quality of individuals, who experienced three-week ketosis, when compared with individuals, who followed a high carbohydrate diet (26). However, the study was conducted among only 11 people, and the high carbohydrate diet was followed by the ketogenic diet in the same participants. The duration of ketosis in this study was very short, while having previously followed a high carbohydrate diet might have masked or prevented the effects of a ketogenic diet. Therefore, the results are likely to be misleading and unsuitable for deriving insights into the longterm effects of a ketogenic diet.

A study that examined comments written on online forums about ketogenic diets concluded that ketogenic dieters experience a more stable mood (27). Yet, the methodical and scientific design of this study are questionable, as the researchers only evaluated the opinions of certain individuals who left comments on forums.

In another study reviewing the different mechanisms of the ketogenic diet, it was emphasized that there were no human studies before 2018, but the ketogenic diet is a promising treatment option, especially in the treatment of mood disorders, due to its anti-depressive effects (13).

In a study, it was found that in pediatric patients who received ketogenic diet in the treatment of epileptic attacks, ketogenic diet after 6 months of diet caused a slight improvement in cognitive functions that was not statistically significant, but could cause psychosocial deterioration and mood disorders (14). Although this study was conducted on a small number of patients $(n=11)$, it is important to argue that mood disorder may occur in individuals on ketogenic diets.

By establishing a relationship between low-carb diets and euphoria, a hypothesis has been proposed that ketosis induces GABA receptors, showing similar effects to gamma hydroxybutyrate in the brain (28). This study supports our study on the 
bipolar disorder-producing nature of the ketogenic diet by trying to explain the mechanisms of action of ketosis that cause mania symptoms.

Limitations: In our study, it was questioned whether participants had any known psychiatric diseases and used any psychiatric drugs for any reason. However, since the presence of mood disorders before the ketogenic diet was not investigated and known, it could not be compared with the aftermath. On the other hand, according to the participants' own statements, it was accepted that they were ketosis positive and ketosis was not detected by urinalysis by us. As another limitation, when ketone positivity was detected, the person was considered as ketone positive and was included in the study. However, it is not known whether the participants paid attention to their diet and kept themselves in constant ketosis states. In addition, our study showed that participants had higher rates of mood disorders, which means they are more active, more social, and more energetic than usual, so they may be more likely to be more engaged and responsive to our study.

In our study, for the first time in the literature, mood disorders were screened with the "Mood Disorder Questionnaire" on individuals who had a ketogenic diet and who had no known psychiatric disease before. According to the results, mood disorder was found at a rate of $26.7 \%$ higher than expected in the general population. This result reveals the necessity of screening for mood disorders in individuals on ketogenic diet and the necessity of avoiding ketogenic diet in patients at risk.

Ethics Committee Approval: Ethics Committee approval was obtained from the Clinical Research Committee of Ataturk University Faculty of Medicine, with the decision date and number of 27.06.2019/05-02.

\section{References}

1. Höhn S, Dozières-Puyravel B, Auvin S. History of dietary treatment from Wilder's hypothesis to the first open studies in the 1920s. Epilepsy Behav. 2019;101:106588.

2. Peterman MG. The ketogenic diet in the treatment of epilepsy: A Preliminary Report. Am J Dis Child. 1924;28(1):28-33.

3. Wheless JW. History of the ketogenic diet. Epilepsia. 2008;49(8):3-5.

4. Mohorko N, Černelič-Bizjak M, Poklar-Vatovec T, et al. Weight loss, improved physical performance, cognitive function, eating behavior, and metabolic profile in a 12-week ketogenic diet in obese adults. Nutrition Res. 2019;62:64-77.

5. Kosinski C, Jornayvaz FR. Effects of ketogenic diets on cardiovascular risk factors: Evidence from animal and human studies. Nutrients. 2017;9(5):517.

6. Gasior M, Rogawski MA, Hartman AL. Neuroprotective and disease-modifying effects of the ketogenic diet. Behav Pharmacol. 2006;17(5-6):431-9.
7. Murphy P, Likhodii S, Nylen K, et al. The antidepressant properties of the ketogenic diet. Biol Psychiatry. 2004;56(12):981-3.

8. Merikangas KR, Akiskal HS, Angst J, et al. Lifetime and 12month prevalence of bipolar spectrum disorder in the National Comorbidity Survey replication. Arch Gen Psychiatry. 2007;64(5):543-52.

9. Grande I, Berk M, Birmaher B, et al. Bipolar disorder. Lancet. 2016;387(10027):1561-72.

10. Kayhan F, Cicek E, Uguz F, et al. Mood and anxiety disorders among inpatients of a university hospital in Turkey. Gen Hosp Psychiatry. 2013;35(4):417-22.

11. Uguz F, Yakut E, Aydogan S, et al. Prevalence of mood and anxiety disorders during pregnancy: A case-control study with a large sample size. Psychiatry Res. 2019;272:316-8.

12. Godart N, Radon L, Curt F, et al. Mood disorders in eating disorder patients: Prevalence and chronology of ONSET. J Affect Disord. 2015;185:115-22.

13. Brietzke E, Mansur RB, Subramaniapillai M, et al. Ketogenic diet as a metabolic therapy for mood disorders: Evidence and developments. Neurosci Biobehav Rev. 2018;94:11-6.

14. Lambrechts DA, Bovens MJ, de la Parra NM, et al. Ketogenic diet effects on cognition, mood, and psychosocial adjustment in children. Acta Neurol Scand. 2013;127(2):103-8.

15. Bostock ECS, Kirkby KC, Taylor BVM. The current status of the ketogenic diet in psychiatry. Front Psychiatry. 2017;8:43

16. Rakofsky J, Rapaport M. Mood Disorders. Continuum: Lifelong Learning in Neurology. 2018;24(3):804-27.

17. Hirschfeld R, Williams J, Spitzer R, et al. Development and validation of a screening instrument for bipolar spectrum disorder: The mood disorder questionnaire. Am J Psychiatry. 2000;157:1873-5.

18. Konuk N, Kiran S, Tamam L, et al. Validation of the Turkish version of the mood disorder questionnaire for screening bipolar disorders. Turk Psikiyatri Derg. 2007;18(2):147-54.

19. Miller CJ, Klugman J, Berv DA, et al. Sensitivity and specificity of the Mood Disorder Questionnaire for detecting bipolar disorder. J Affect Disord. 2004;81(2):167-71.

20. Williams N. The Mood Disorder Questionnaire. Occup Med (Lond). 2017;67(2):165-6.

21. Clemente AS, Diniz BS, Nicolato R, et al. Bipolar disorder prevalence: a systematic review and meta-analysis of the literature. Braz J Psychiatry. 2015;37(2):155-61.

22. Moreira ALR, Van Meter A, Genzlinger J, et al. Review and meta-analysis of epidemiologic studies of adult bipolar disorder. J Clin Psychiatry. 2017;78(9):1259-69.

23. Joslyn C, Hawes DJ, Hunt C, et al. Is age of onset associated with severity, prognosis, and clinical features in bipolar disorder? A meta-analytic review. Bipolar Disord. 2016;18(5):389-403.

24. McClernon FJ, Yancy Jr WS, Eberstein JA, et al. The effects of a low-carbohydrate ketogenic diet and a low-fat diet on mood, hunger, and other self-reported symptoms. Obesity. 2007;15(1): 182 .

25. Phelps JR, Siemers SV, El-Mallakh RS. The ketogenic diet for type II bipolar disorder. Neurocase. 2013;19(5):423-6.

26. Iacovides S, Goble D, Paterson B, et al. Three consecutive weeks of nutritional ketosis has no effect on cognitive function, sleep, and mood compared with a highcarbohydrate, low-fat diet in healthy individuals: a randomized, crossover, controlled trial. Am J Clin Nutr. 2019;110(2):349-57.

27. Campbell $\mathrm{IH}$, Campbell H. Ketosis and bipolar disorder: controlled analytic study of online reports. B J Psych Open. 2019;5(4):e58

28. Brown AJ. Low-carb diets, fasting and euphoria: Is there a link between ketosis and $\gamma$-hydroxybutyrate (GHB)? Med Hypotheses. 2007;68(2):268-71. 